\title{
Fiscal Multipliers for Saudi Arabia Revisited
}

H.E. Dr. Majid Al Moneef and Fakhri Hasanov 


\section{About KAPSARC}

The King Abdullah Petroleum Studies and Research Center (KAPSARC) is a non-profit global institution dedicated to independent research into energy economics, policy, technology and the environment across all types of energy. KAPSARC's mandate is to advance the understanding of energy challenges and opportunities facing the world today and tomorrow, through unbiased, independent, and high-caliber research for the benefit of society. KAPSARC is located in Riyadh, Saudi Arabia.

This publication is also available in Arabic.

\section{Legal Notice}

(C) Copyright 2020 King Abdullah Petroleum Studies and Research Center ("KAPSARC"). This Document (and any information, data or materials contained therein) (the "Document") shall not be used without the proper attribution to KAPSARC. The Document shall not be reproduced, in whole or in part, without the written permission of KAPSARC. KAPSARC makes no warranty, representation or undertaking whether expressed or implied, nor does it assume any legal liability, whether direct or indirect, or responsibility for the accuracy, completeness, or usefulness of any information that is contained in the Document. Nothing in the Document constitutes or shall be implied to constitute advice, recommendation or option. The views and opinions expressed in this publication are those of the authors and do not necessarily reflect the official views or position of KAPSARC. 


\section{Key Points}

This research examines fiscal spending multipliers for Saudi Arabia's non-oil private sector.

The study period, 1983-2018, includes the recent low oil-price environment.

It addresses integration-cointegration and exogeneity properties of the data, unlike most previous studies.

Main findings:

The current spending multiplier is larger in the short run and smaller in the long run.

The capital spending multiplier is smaller in the short run and larger in the long run.

There is a higher spending multiplier during economic recessions and an insignificant one during economic expansions.

The multipliers are slightly smaller than those found in previous studies.

Main policy insights:

Fiscal policy plays an important role in the growth of the non-oil private sector.

Fiscal authorities may consider implementing selective countercyclical fiscal policy to better support economic growth and efficiency in spending. These are key objectives of Saudi Vision 2030's Fiscal Balance Program. 
F iscal policy lies at the heart of key macroeconomic and budgetary decisions and is central to understanding the dynamics of oil rich economies. Fiscal multipliers, including spending multipliers, indicate how changes to fiscal policy can stimulate economic growth, to what magnitude, and how efficiently, making them valuable tools for macroeconomic planning and analysis. They allow a government to better evaluate budgetary options and project revenue under given macroeconomic conditions, in order to balance goals such as inclusive growth and targeted national savings rates with the constraints of taxation and central government debt.

Many factors influence the size of fiscal multipliers, including trade openness, exchange rate regime, debt levels, automatic stabilizers, labor market flexibility, and monetary policy. The changes in the business cycle also play an important role in the effectiveness of the multiplier. An International Monetary Fund (IMF) study found that fiscal multipliers are generally larger during economic recessions than in expansions, because at full capacity, an increase in public demand crowds out private demand, leaving output unchanged while pushing up inflation (Batini et al. 2014).

Fiscal multipliers play a critical role in resource rich economies such as Saudi Arabia, where oil revenues accrue to the state, which in turn spends much of this income on stimulating the nonoil sector. Historically, government expenditure has played a pivotal role in the Saudi economy, contributing an annual average of $37 \%$ of nominal gross domestic product (GDP) from 1983 to 2018. This is higher than the world average of $27 \%$ during the same period, and is $58 \%$ of Saudi Arabia's nominal non-oil GDP (SAMA 2020; WB 2019). ${ }^{1}$ Like many other developing and resource-dependent economies, Saudi Arabia has generally exhibited procyclical fiscal policy, with expenditure increasing by $6 \%$ annually from 1983 to 2018 . However, expenditure stagnated at $0.2 \%$ annually during the 1983-1999 downturn, before recovering and growing by $13 \%$ annually during the expansion from 2000 to 2014 . Following this period, expenditure slowed by $0.3 \%$ per annum as international oil prices weakened. During the boom years of 2004-2014, the fiscal surplus averaged 186 billion Saudi Arabian riyals (SAR) versus an average deficit of 278 billion SAR since 2015 (SAMA 2020).

Various studies have addressed different aspects of Saudi Arabia's fiscal development. Looney (1989) studied the efficacy of fiscal and monetary policy in Saudi Arabia from 1960 to 1985 . He suggested the superiority of simple fiscal rules over optimally designed discretionary policy in increasing non-oil GDP growth. Joharji and Starr (2010) examined the relationship between government expenditure and non-oil GDP in Saudi Arabia from 1969 to 2005 and found that the government's current expenditure has a larger long-run effect on GDP growth than its capital expenditure. Ghali (1997), using a vector autoregression (VAR) model to examine the intertemporal interactions among the growth rate in per capita real GDP and the share of government spending in GDP, observed no consistent evidence that government spending could increase Saudi Arabia's per capita output growth for the period 1960-1996. Alshahrani and Alsadiq (2014) analyzed the short- and long-run effects of different types of government expenditure on growth from 1969 to 2010. Almarzoqi and El Mahmah (2019) built a small-scale macroeconometric model for the Saudi economy for the period 1990-2018. They found that rising non-oil revenue has fueled government spending, leading to an increase in total consumption and private investment in small magnitude. However, this continued rise in revenue, 
through cutting incentives, implementing a valueadded tax (VAT) and introducing fees and taxes, put more pressure on the private sector and disposable income and thereby would weaken investment and consumption in the long run. The summary of the findings of the above studies mainly indicates that while private domestic and public investments, as well as healthcare expenditure, stimulate growth in the long run, openness to trade and spending in the housing sector can also boost short-run production. ${ }^{2}$

This research investigates fiscal spending multipliers for Saudi Arabia and makes the following contributions to the literature.

(a) The study addresses the stochastic properties of the data by conducting unit root and cointegration tests. Additionally, it performs exogeneity tests to ensure that the fiscal variables are exogenous to non-oil private sector GDP.

(b) It takes non-oil private sector GDP as a dependent variable, whereas previous fiscal multiplier studies for Saudi Arabia have considered non-oil GDP, a sum of private and government sectors. The former provides a better understanding than the latter of the diversification of the Saudi economy and the role of fiscal policy in developing the private sector.

(c) It estimates multipliers for current, capital, and total government spending.

(d) It assesses both short-run and long-run spending multipliers for a sample span that includes the recent low oil-price environment.

(e) It measures fiscal multipliers during periods of expansion and recession for Saudi Arabia's economy.
The paper is structured as follows: Section 2 provides a background on the Kingdom's economy and Section 3 reviews previous multiplier studies on the country. Section 4 introduces the data. Section 5 elaborates the research strategy and econometric methods used. Sections 6 delineates and discusses the results of the empirical analysis. Finally, Section 7 concludes with policy insights and recommendations. 


\section{Background: Fiscal Spending and Private Sector Growth in Saudi Arabia}

ince oil was discovered in Saudi Arabia in 1938 and exported thereafter, the

government's revenues accrued through taxes and royalties quickly became its main source of revenues, dwarfing total non-oil revenues. As a result, fiscal policy started to play a significant role in the Kingdom's economic and social development. This role took a new shape during the first oil boom of the 1970s.

Figure 1 illustrates the close relationship between non-oil private sector GDP and government spending from 1983 to 2018 . $^{3}$

Over this period, real expenditure grew by an average of $5 \%$ and non-oil private sector GDP averaged $4 \%$ annual growth. However, the pattern of growth differed with the oil price (and revenue) cycles. When oil prices declined and subsequently stagnated from 1983 to 2002, both real government spending and non-oil private GDP increased at average annual rates of just $1.9 \%$ and $1.7 \%$, respectively. During the 1983-1986 period, when government revenues declined from 206 billion SAR in 1983 to 76 billion SAR in 1986, due to the decline in the price of Arabian light crude from \$29.8 per barrel (b) to $\$ 14.5 / b$, the real expenditure and non-oil private sector GDP declined by $12 \%$ and $4 \%$ annually, respectively. The price recovery after 2000 , and its continued rise until 2014 , led to a remarkable increase in government revenues from 147 billion SAR in 1999 to a high of 1,247 billion

Figure 1. Growth in real government expenditure and non-oil private sector GDP, \% (1983-2018).

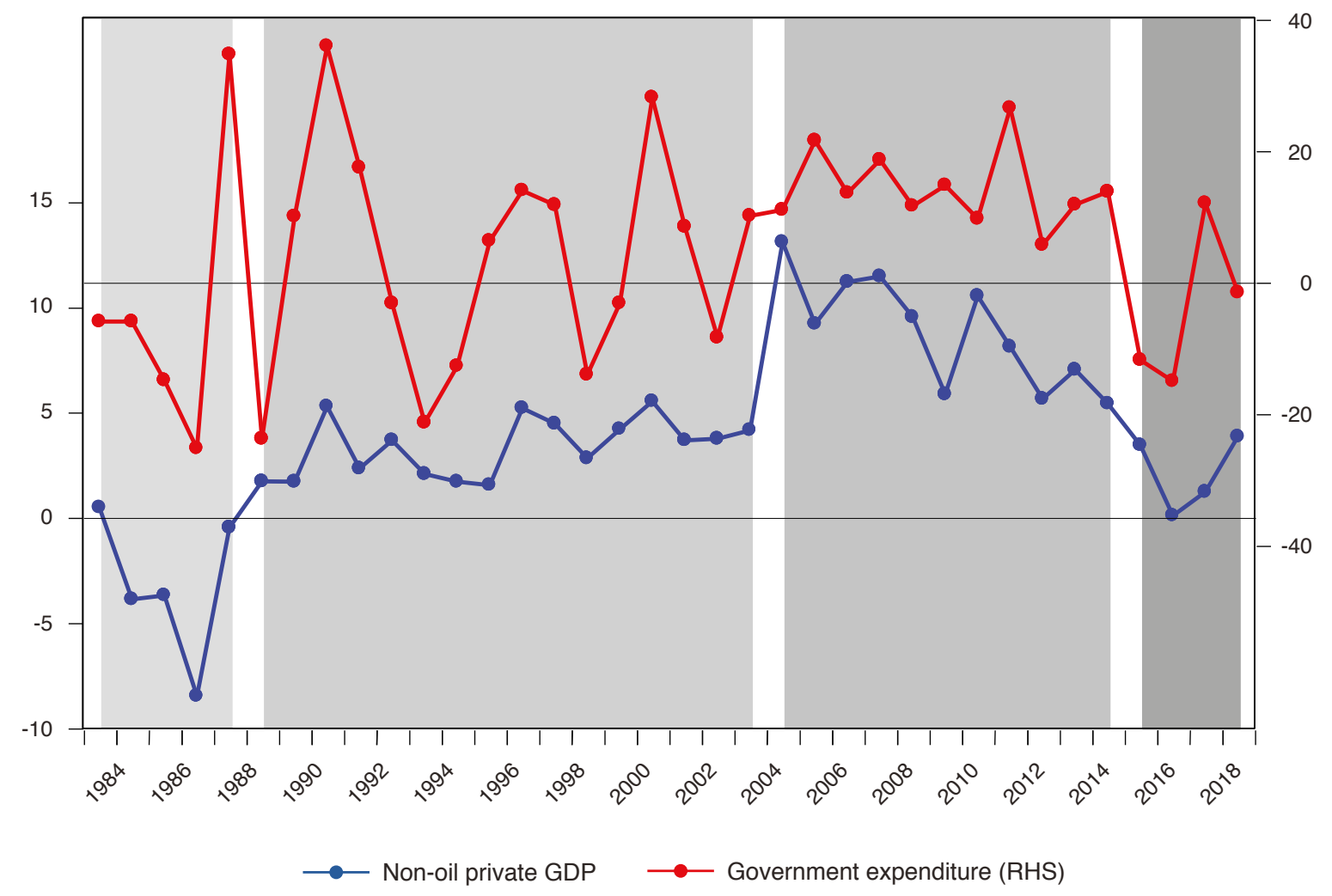

Source: Authors' calculation using SAMA (2020). 
SAR in 2012. This represented an annual average increase of $23 \%$ during the $2000-2014$ period.

During this boom, real government expenditure grew by an annual average of $11 \%$ and private non-oil GDP by $8 \%$. When oil prices and revenues started to decline in 2014, expenditure declined from 1,141 billion SAR in 2014 to 930 billion SAR in 2017, before rising to 1,079 billion SAR in 2018, while private non-oil GDP grew by an annual average of $1.7 \%$ from 2015 to 2018 (SAMA 2020).

Fiscal policy in Saudi Arabia is shaped largely by oil revenues rather than taxes collected from the non-oil sector and, as is the case for many developing and more so resource-rich countries, this policy has been procyclical over the years. The historical trends detailed above demonstrate that government spending can be considered as one of the main drivers of private sector growth. The changes in expenditure following oil market cycles were not uniform across current and capital spending. Current expenditure increased by annual averages of $41 \%$ and $12 \%$ during the first and second booms of 1974-1982 and 2000-2014, respectively. Capital expenditure increased by annual averages of $40 \%$ and $25 \%$ in the first and second booms, respectively. From 1983 to 2000, capital expenditure jumped dramatically, while current expenditure, due to its rigidity, grew by $6 \%$ annually.

In 2016, due to the continued volatility in oil prices, which translated into volatile revenues and government expenditure, and the dismal record of diversifying the Saudi economy over the past four decades, the government launched wide-ranging reforms under Saudi Vision 2030, with different programs such as the Fiscal Balance Program (FBP). The major goals of Vision 2030 are to create sustainable government finances, economic growth and a more diversified and productive economy.
The FBP aims to rationalize expenditure, reform the incentive systems, and increase non-oil revenues through energy price reforms, non-resident fees, value-added tax, and other measures (FBP 2019). Although some measures might have adverse effects on private consumption and investment in the short run, it is believed that their long-run impact will stimulate the non-oil economy and lessen the degree of fiscal dependence on oil receipts (see e.g., Hasanov et al. 2020b). The government's nonoil revenues have increased significantly since these reforms were implemented, rising by $12 \%, 38 \%$ and $30 \%$ in 2016, 2017 and 2018, respectively. These rates are high by historical standards, particularly given slow overall economic growth during this period. Furthermore, the acceleration of non-oil revenue collection came alongside positive, though lower, growth in private sector GDP, as Figure 1 illustrates (see also Almarzoqi and El Mahmah 2019). It is difficult to assess whether the slower growth in private sector activity is mainly due to the decline in government spending or increase in fees and taxes, or both. Nevertheless, it is noteworthy that non-oil private sector GDP growth remained positive despite tighter fiscal policy. 


\section{Literature Review}

iscal multipliers have been increasingly used in macroeconomic analysis to support policymaking. The sizes and signs of multipliers provide valuable guidance about shortand long-term impacts of fiscal policy decisions. However, few studies using time series data have been conducted on fiscal multipliers in Saudi Arabia ${ }^{4}$ and their findings differ according to the chosen time periods, data, proxies for fiscal variables, and approaches. In the literature, estimates of short-term multipliers for government capital expenditure using annual data range from 0.2 to 0.5 and for current spending from 0.1 to 0.3 . Long-run multipliers for capital expenditure vary from 0.6 to 1.0 and for current spending from 0.1 to 0.5 , as shown in Table 1 .

Table 1. Time series studies of fiscal spending multipliers for Saudi Arabia.

\begin{tabular}{|c|c|c|c|c|c|c|c|}
\hline \multirow{2}{*}{ Study } & \multirow{2}{*}{ Period } & \multirow{2}{*}{ Dependent variable } & \multirow{2}{*}{ Method } & \multirow{2}{*}{ Fiscal variable } & \multicolumn{3}{|c|}{ Multiplier } \\
\hline & & & & & Short-r & un Lo & ong-run \\
\hline \multirow{3}{*}{$\begin{array}{l}\text { Espinoza and } \\
\text { Senhadji }(2011)^{a}\end{array}$} & \multirow{3}{*}{ 1975-2009 } & \multirow{3}{*}{ Non-oil GDP } & \multirow{3}{*}{ VAR } & Total expenditure & 0.2 & & 0.5 \\
\hline & & & & Capital expenditure & 0.5 & & 1.0 \\
\hline & & & & Current expenditure & 0.1 & & 0.1 \\
\hline $\begin{array}{l}\text { Espinoza et al. } \\
(2013)\end{array}$ & NA & Non-oil GDP & VAR & Total expenditure & 0.1 & & - \\
\hline \multirow{2}{*}{ IMF (2016) } & \multirow{2}{*}{ 1980-2015 } & \multirow{2}{*}{ Non-oil GDP } & \multirow{2}{*}{ VAR } & Capital expenditure & 0.2 & & 0.8 \\
\hline & & & & Current expenditure & 0.3 & & 0.5 \\
\hline \multirow{2}{*}{$\operatorname{IMF}(2017)^{\mathrm{b}}$} & \multirow{2}{*}{ 1990-2016 } & \multirow{2}{*}{ Non-oil GDP } & \multirow{2}{*}{$\mathrm{RC}$} & Capital expenditure & & & 0.6 \\
\hline & & & & Current expenditure & & & 0.5 \\
\hline \multirow{2}{*}{ Al-Abri et al. (2018) } & \multirow{2}{*}{$1980-2015$} & \multirow{2}{*}{ Non-oil GDP } & \multirow{2}{*}{ VAR } & \multirow{2}{*}{ Total expenditure } & 2-year & \\
\hline & & & & & 0.9 & & \\
\hline \multirow{5}{*}{$\begin{array}{l}\text { Hemrit and } \\
\text { Benlagha (2018)c }\end{array}$} & \multirow{5}{*}{ 1970-2015 } & \multirow{5}{*}{ Non-oil GDP } & \multirow{5}{*}{ SVAR } & & $\begin{array}{c}2 \\
\text { - year }\end{array}$ & $\begin{array}{c}4 \\
- \text { year } \\
\end{array}$ & Peak \\
\hline & & & & Agriculture expenditure & 0.43 & 0.58 & 0.59 \\
\hline & & & & Health expenditure & 0.95 & 0.68 & 0.71 \\
\hline & & & & Construction expenditure & 0.11 & 0.76 & 0.47 \\
\hline & & & & $\begin{array}{l}\text { Transport, storage } \\
\text { and communication } \\
\text { expenditure }\end{array}$ & 0.06 & 0.60 & 0.33 \\
\hline
\end{tabular}

Note: $\mathrm{VAR}=$ vector autoregression; $\mathrm{RC}=$ rolling correlations; SVAR= structural vector autoregression;

a. short-run and long-run multipliers represent the first year and three years, respectively, after a shock;

b. the IMF (2017) does not specify whether the estimated multipliers are for short- or long-run. We treat them as long-run multipliers based on previous IMF (2016) study;

c. the peak corresponds to the ratio of the coefficients of the non-oil sector and government expenditure at their respective peaks. 


\section{Data}

$\mathrm{n}$ this study, we employ annual time series data for the period 1983-2018, in constant 2010 million

Saudi Arabian riyal (SAR) (unless otherwise stated), and define key variables as follow:

$Y$ is the value added of the non-oil private sector.

$G T$ is real government total spending.

$G C U$ is real current government expenditure.

This is the sum of government final consumption expenditure on goods and services for current use (e.g., operational and maintenance spending and employee compensation) and transfers (e.g., payments for social security, pensions, and unemployment benefits).

$G C A$ is real capital government expenditure representing spending for the future, such as investments in infrastructure, transport, health, communication, and spending on education, research and defense. Tables 4 and 7 of NA (2017) provide details of government final consumption and capital expenditures in Saudi Arabia.

$Y W$ is real world GDP in constant 2015 US\$ million.

We obtained annual time series data for all variables from the Saudi Arabian Monetary Authority yearly statistics (SAMA 2017, 2018; OE 2017), except for real world GDP, which comes from the Oxford Economics Database May 2016 release (OE 2016). Nominal values for government expenditure variables ${ }^{5}$ were deflated by the $\mathrm{CPI}^{6}(2010=100)$ to obtain real values, following previous fiscal studies for Saudi Arabia.

Figure 2 below illustrates the natural logarithmic levels (lower case letters) and growth rates of the variables over the study period of 1983-2018.

Figure 2. The log levels and growth rates of the variables.

Panel A. Log level of the variables
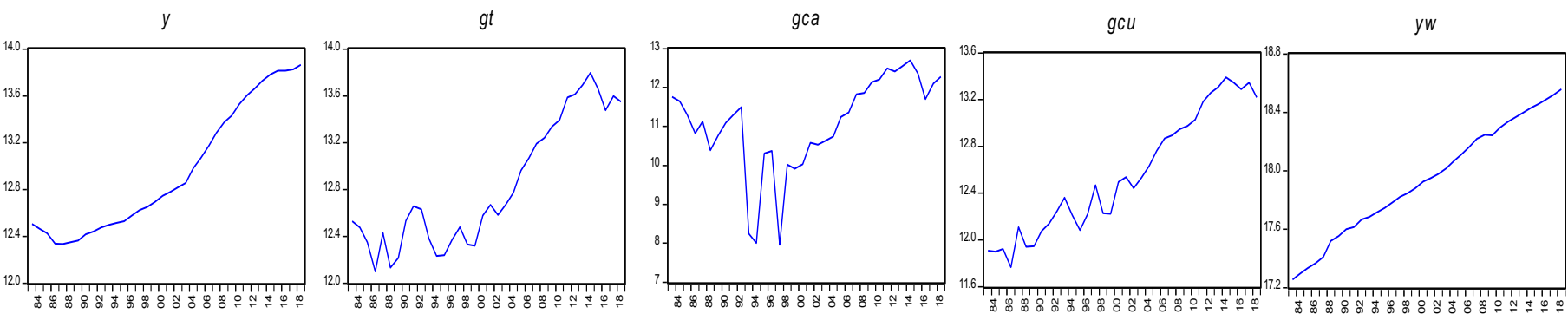

Panel B. Growth rates of the variables

$d(y)$

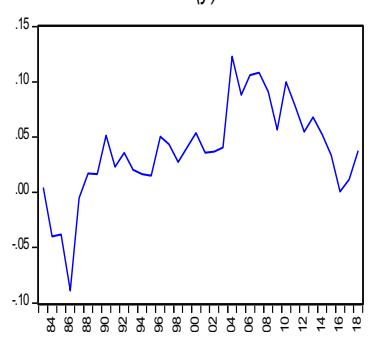

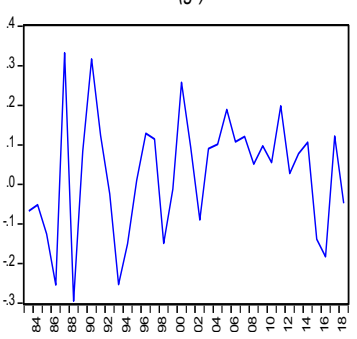

$d(g c a)$

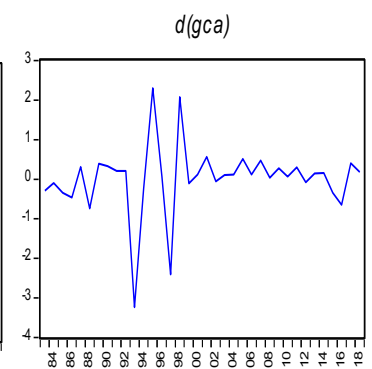

$d(g c u)$

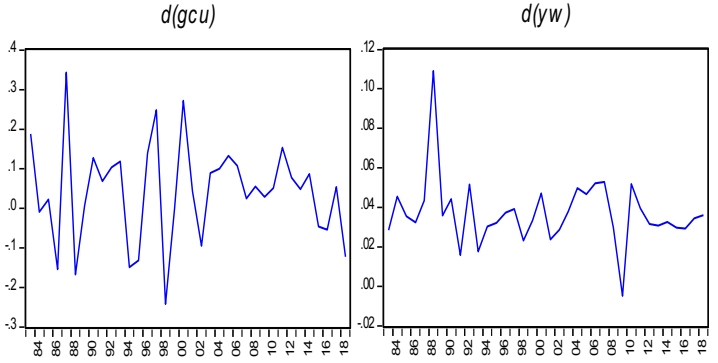

Source: Authors' calculation. 
Some fiscal multiplier studies use cyclically adjusted fiscal indicators to rule out their possible endogeneity. However, we do not take this approach because Espinoza and Senhadji (2011) and Fouejieu et al. (2018), among others, argue that fiscal indicators are not endogenous to domestic economic activity in Saudi Arabia. This is mainly because oil revenues dominate government income, providing $76 \%$ of the budget revenue over the study period, and are largely influenced by global developments in the world oil market. These externally determined revenues and prevailing discretionary fiscal policy preclude the presence of automatic stabilizers. Many studies have referred to this procyclical pattern of the fiscal policy in oil-exporting developing economies including Saudi Arabia (for example: Ilzetzki and Végh 2008; Husain et al. 2008; Sturm et al. 2009; Abdih et al. 2010; Fouejieu et al. 2018). 


\section{Research Strategy and Econometric Methodology}

1

n most cases, macroeconomic time series demonstrate non-stationary behavior and are difference stationary or sometimes trend stationary. For empirical studies, it is important to determine whether differencing or de-trending is the appropriate methodology for a given macroeconomic series. Differencing is suitable for integrated series while de-trending is appropriate for trend stationary time series. Hence, we begin our analysis by assessing the stochastic properties of the time series data using the augmented Dickey-Fuller (ADF) (Dickey and Fuller 1981) and Kwiatkowski-Phillips-Schmidt-Shin (KPSS) (Kwiatkowski et al. 1992) unit root tests. We use these tests because their null hypotheses are different, i.e., the former takes the null hypothesis of unit root while the latter takes the null hypothesis of (trend) stationarity. When needed, we employ the tests with structural breakpoints (Zivot and Andrews 1992; Vogelsang and Perron 1998; Perron 2006).

Once integration orders of the variables are concluded, we test the existence of a long-run relationship between non-oil private sector GDP and government spending. We need to also make sure that the former is impacted by the latter and not vice versa. As emphasized in the literature, fiscal indicators should be exogenous in relation to output when estimating multipliers (Espinoza and Senhadji 2011; Ilzetzki et al. 2013; Ramey 2016). Moreover, since we are estimating the long-run multipliers as well, a long-run relationship between the fiscal variable and non-oil private sector GDP should first be concluded using cointegration test. Otherwise, the long-run results would be only statistical estimations without any support that such relationships exist. We employ the system-based cointegration test method developed by Johansen and Juselius (1992) and Johansen (1995) to check (a) whether the variables are cointegrated and (b) if so, how many cointegrated relations exist. Then, we run the weak exogeneity test in the Johansen method framework to check whether non-oil private sector GDP is impacted by the fiscal variables but not the other way around.

VAR and structural macroeconometric models are the two most commonly used approaches in estimating fiscal multipliers. The former has become increasingly typical in the literature to analyze the dynamic relations among variables and capture their reactions to fiscal shocks (Mustea 2015; Arin et al. 2015). VAR methodology comprehensively addresses problems of endogeneity and simultaneity biases and permits the data to provide indication of dynamic interactions among the variables. Caldara and Kamps (2008) and Mustea (2015) have discussed four different approaches to identify fiscal shocks within a VAR framework. We employ the recursive approach introduced by Sims (1980) and used by Fatas and Mihov (2001), among many others.

We utilize the following VAR model:

$X_{t}=\alpha_{0}+\alpha_{1} t+A(L) X_{t-L}+\varepsilon_{t}$

where $X_{t}$ is the vector of world GDP, a fiscal variable and the non-oil private sector GDP; A(L) is a lag order and $\varepsilon_{\mathrm{t}}$ is the vector of disturbance terms with $\varepsilon_{t} \sim \operatorname{iid}\left(0, \Sigma_{\varepsilon}\right)$.

The recursive VAR approach is based on the ordering of the variables as follows: world GDP, the fiscal variable (total expenditure, current expenditure and capital expenditure), and non-oil private sector GDP. The order assumes that non-oil private sector GDP growth reacts contemporaneously to shocks from the growth rates of a fiscal variable and world GDP; growth rates of the fiscal variable 
react contemporaneously to changes in world GDP growth but not non-oil GDP growth; and world GDP growth does not react contemporaneously to either.

Following the conventional approach in the fiscal multiplier literature, we use growth rates, i.e., the first difference of the natural logarithmic expressions of the variables in VARs, because (a) they are usually stationary and thereby standard statistical inferences are applicable, and (b) the calculated coefficients from the impulse-response analysis can be interpreted as elasticities (Espinoza and Sendhaji 2011; Ilzetzki et al. 2013, inter alia).

Since we have three fiscal variables, we estimate three VARs to evaluate their separate impacts on non-oil private sector GDP.

\section{Multiplier calculations}

Generally, a fiscal multiplier is defined as how much unit output variable will change if the fiscal variable changes one unit. Following the consensus in the multiplier literature, we first calculate the elasticity of the non-oil private sector GDP with respect to a fiscal variable from the impulse-response functions of an estimated VAR. Then we calculate the multiplier as that elasticity divided by the ratio of the mean value of a fiscal variable to the mean value of the non-oil private sector GDP (Espinoza and Sendhaji 2011; Ramey and Zubairy 2018). We first estimate the short-run $\left(\mathrm{m}_{\mathrm{sr}}\right)$, or the impact multiplier, which shows the contemporaneous change in the output variable $(\mathrm{Y})$ due to the contemporaneous change in the fiscal variable $(G)$ :

$m_{s r}=\frac{\Delta Y_{t}}{\Delta G_{t}}$

Ramey and Zubairy (2018) highlighted the pitfalls of calculating multipliers as the ratio of the peak of the output response to the initial fiscal spending shock and, hence, we do not do so. Following Mountford and Uhlig (2009), Uhlig (2010), and Fisher and Peters (2010), we calculated the long-run multiplier $\left(\mathrm{m}_{\mathrm{lr}}\right)$ as the ratio of the cumulative change in the output response to the cumulative change in fiscal spending as follows:

$m_{l r}=\frac{\sum_{t=1}^{T} \Delta Y_{t}}{\sum_{t=1}^{T} \Delta G_{t}}$

Where, $\mathrm{T}$ is the time horizon. 


\section{Empirical Analysis and Discussion}

\section{The results of unit root,} cointegration and weak exogeneity tests

The augmented Dickey-Fuller (ADF) and Kwiatkowski-Phillips-Schmidt-Shin (KPSS) unit root tests results are shown in Table 2. For the log levels of the variables, the ADF test results fail to reject the null hypothesis of the presence of a unit root with the exception of $y$ and $g c u$, while the
KPSS test results reject the null hypothesis of trend stationarity in all cases. For the growth rates, i.e., the first differences of the log levels of the variables, the ADF test results reject the null hypothesis of a unit root even at the $1 \%$ significance level, while the KPSS test results fail to reject the null hypothesis of stationarity, except for $\Delta y$ in both the tests. Thus, according to both the tests, we can conclude that $g c a, g c u, g t, y w$ are unit root processes but their first differences are stationary, meaning that they follow I(1) processes.

Table 2. Unit root tests results.

\begin{tabular}{|c|c|c|c|c|c|}
\hline Variable & $\begin{array}{l}\text { The ADF t } \\
\text { Test value }\end{array}$ & $\mathrm{C}$ & $\mathrm{t}$ & None $^{1}$ & $\mathrm{k}$ \\
\hline gcu & $-3.30^{c}$ & & $x$ & & 0 \\
\hline y & $-3.63^{b}$ & & $x$ & & 1 \\
\hline gca & -1.86 & & $x$ & & 2 \\
\hline gt & -2.56 & & $x$ & & 0 \\
\hline yw & -2.17 & & $x$ & & 0 \\
\hline$\Delta \mathrm{gcu}$ & $-7.53^{a}$ & & & $x$ & 1 \\
\hline$\Delta \mathrm{y}$ & -3.00 & & $x$ & & 0 \\
\hline$\Delta \mathrm{gca}$ & $-7.67^{a}$ & & & $x$ & 1 \\
\hline$\Delta \mathrm{gt}$ & $-5.71^{a}$ & & & $x$ & 0 \\
\hline$\Delta y w$ & $-5.99^{a}$ & $x$ & & & 0 \\
\hline
\end{tabular}

\begin{tabular}{lll} 
The KPSS test & & \\
Test value & $\mathrm{C}$ & $\mathrm{t}$ \\
\hline $0.14^{\mathrm{b}}$ & $\mathrm{x}$ \\
\hline $0.20^{\mathrm{b}}$ & $\mathrm{x}$ \\
\hline $0.17^{\mathrm{b}}$ & $\mathrm{x}$ \\
\hline $0.17^{\mathrm{b}}$ & $\mathrm{x}$ \\
\hline $0.10^{\mathrm{a}}$ & $\mathrm{x}$ & \\
\hline 0.26 & $\mathrm{x}$ \\
\hline $0.45^{\mathrm{c}}$ & $\mathrm{x}$ \\
\hline 0.23 & $\mathrm{x}$ \\
\hline 0.21 & \\
\hline 0.18 & \\
\hline
\end{tabular}

Notes: The maximum lag order is set to two and the optimal lag order $(\mathrm{k})$ is selected based on Schwarz criterion in the test equations; $a, b$, and $c$ indicate rejection of the null hypotheses at the $1 \%, 5 \%$ and $10 \%$ significance levels, respectively; ${ }^{1}$ neither intercept nor trend is included in test equations; $x$ indicates that the corresponding option is selected in the test equations. The estimation period is $1983-2018$. 
The main variable of interest, $y$, requires further investigation as the results of the ADF and KPSS tests contrast but both tests confirm that its first difference is non-stationary. However, concluding that $y$ is a second difference stationary variable, i.e., integrated of order two, I(2) does not seem reasonable for the following reasons. First, Panel A of Figure 2 illustrates that y has a noticeable break in its development path since 2004. It is probable that the results from the ADF and KPSS tests about the integration order of $d(y)$ might be caused by this break. ${ }^{7}$ It is well known that conventional unit root tests have less power in case of structural breaks and thereby may produce misleading results (Perron 2006; Enders and Lee 2012a, 2012b). Second, Juselius (2006) discusses that it is not reasonable to conclude that a given variable is I(2) process if the sample span is around 10-30 years. Lastly, earlier studies found non-oil GDP to be an I(1) process (see Hasanov et al. 2020a, inter alia). To this end, we implement the ADF test, which accounts for possible structural breaks as discussed in the methodological section. To test $y$, we set the maximum lag at two and employ the Schwarz information criterion to specify the optimum lag length. We consider the break in trend in 2004 as an additive break since it happens suddenly. We find the sample statistic is -2.07 and in absolute terms it is smaller than the critical values at the $1 \%, 5 \%$, and $10 \%$ significance levels, i.e., $-4.50,-3.93$ and -3.64 , respectively. In other words, the null hypothesis that y follows a unit root process with a structural break cannot be rejected. For testing $d(y)$, we follow the same steps and consider an additive break in the variable in 2004 . The estimated sample value of -4.57 is greater than the critical value of -4.23 at the $5 \%$ significance level in absolute terms, suggesting that $\mathrm{d}(\mathrm{y})$ is a stationary process. Thus, we conclude, based upon the unit root test results, that all the variables are non-stationary at their log levels but their growth rates are stationary, i.e. they are I(1) processes.

Next, we test for cointegration and weak exogeneity in the vector error correction (VEC) modeling framework. We formulate three separate VEC models, named VEC1, VEC2 and VEC3, since we are investigating the impacts of the total, capital and current government expenditures on non-oil private sector GDP separately. To save space in the main text and avoid technicality, we report VAR/ VEC estimation and test results in Appendix A. The results shown in Table A1 indicate that there is only one cointegrated relationship in all three VEC models regardless of whether only intercept or both intercept and linear trend are included in the cointegration equations. In other words, fiscal variables, global GDP and non-oil private sector GDP establish a long-run relationship. Moreover, the table reports that weak exogeneity holds firm, assuming the disequilibrium of the long-run relationship enters only in non-oil private sector GDP equation but not in the other two. Put differently, the world GDP and fiscal variables impact nonoil private sector GDP contemporaneously, but the opposite is not true. These findings provide a foundation for the next step of assessing the multipliers.

\section{The impulse-response analysis and multipliers}

Having concluded in the previous subsection that the variables are cointegrated and that both fiscal variables and world GDP are exogenous to non-oil private sector GDP, we estimate three VAR models and perform an impulse-response analysis to calculate the multiplier effects of the government's total, current, and capital expenditures on non-oil private sector GDP. ${ }^{8}$ Post-estimation test results 
reported in Table A2 of Appendix A indicate that the estimated VAR models do not have any issues of instability, serial correlation, non-normality, or heteroscedasticity; hence they are well-specified and can be used for the impulse-response analysis. Figure 3 illustrates the cumulative effects of shocks
(Cholesky one standard deviation degree of freedom adjusted innovations) to the growth rates of world GDP, fiscal indicators, and non-oil private sector GDP on non-oil private sector GDP growth in a 10-year horizon.

Figure 3. The accumulated responses of non-oil private sector GDP growth, $\Delta y$.

\section{Panel A. Shocks to}
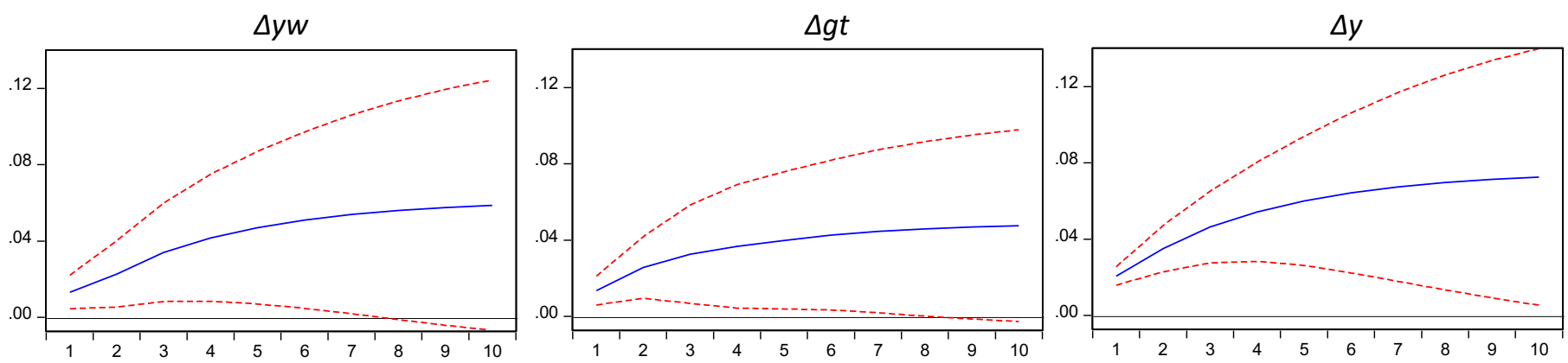

Panel B. Shocks to
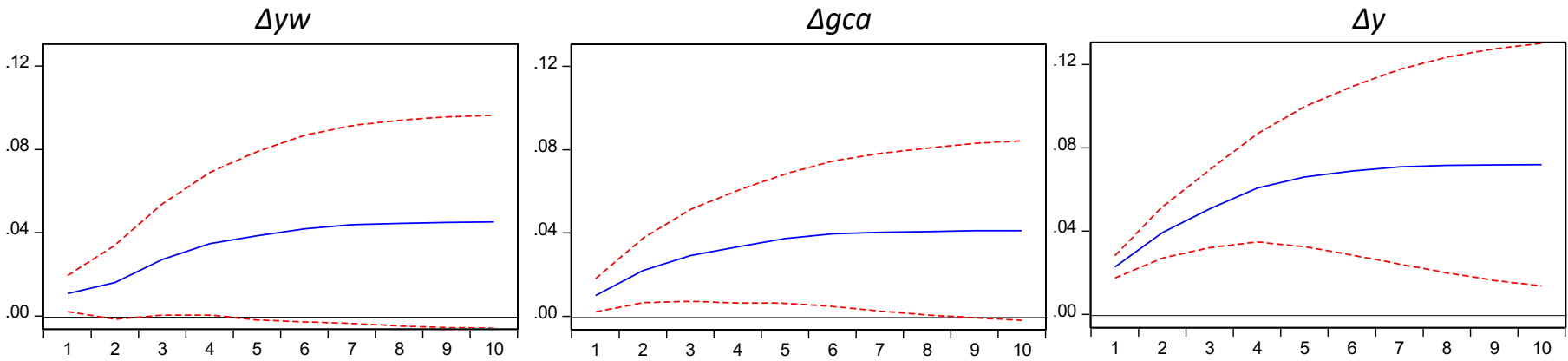

Panel C. Shocks to
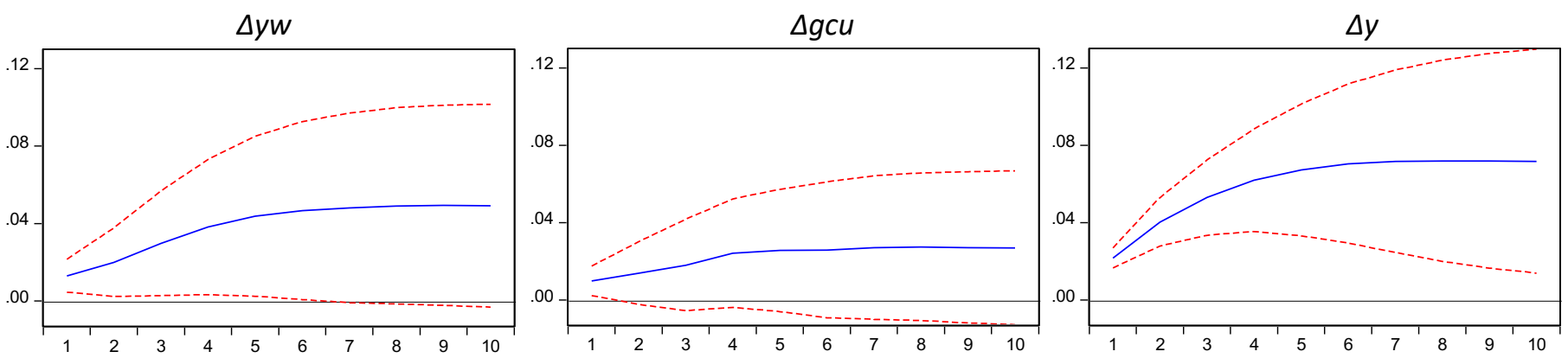
The impulse-response results are consistent. For example, all the panels in Figure 3 illustrate positive impacts on non-oil private sector GDP growth from shocks to the growth rates of world GDP and fiscal indicators. The graphs in the third column also show the positive self-impact of non-oil private sector GDP growth.

The positive impact of world GDP growth on Saudi Arabia's non-oil private sector growth indicates that global growth drives greater demand for the Kingdom's goods and services, primarily energy exports, which in turn boosts the Kingdom's overall domestic activity (see the graphs in the first column). This finding is consistent with studies by Espinoza and Senhadji (2011) and Fouejieu et al. (2018), which confirm that external demand increases Saudi Arabia's exports and, consequently, economic activity. Non-oil private exports as a portion of total Saudi exports is reflected directly in the demand side representation of non-oil private sector GDP. Oil exports, the revenues of which accrue to the government, can also positively impact non-oil private sector GDP through government expenditures.

Moreover, the second and third graphs in the middle column of Figure 3 illustrate that shocks to capital expenditures have more persistent positive effects than those to current expenditures on non-oil private sector GDP, with the first lasting seven and a half years versus two years for the second. The first middle graph also shows a persistent effect of total expenditures on the non-oil private sector GDP, because of the overwhelming impact of capital spending.

Table 3 presents the calculated immediate (short-run) and cumulative (long-run) multipliers of fiscal expenditures for non-oil private sector GDP in Saudi Arabia.

As expected, the table shows that multipliers for total government spending are small in the short run and large in the long run. Capital and current expenditure exhibit differences in the short and long run. Capital spending has the lowest multiplier for the short run but the highest for the long run. It reaches its peak value of 0.56 three years after a shock and then gradually declines to 0.47 . Current spending is higher than capital spending in the short run. It hits 0.32 after two years but it is not statistically significant at the $5 \%$ level.

The results indicate that, if the government increases capital or current spending by 100 SAR each, then non-oil private sector GDP will grow in the short term by 13 SAR and 8 SAR, respectively.

Table 3. Short- and long-run fiscal multipliers.

\begin{tabular}{lcc} 
Fiscal variable & Multiplier & Long-run \\
\hline Total expenditure & Short-run & 0.41 \\
\hline Capital expenditure & 0.11 & 0.47 \\
\hline Current expenditure & 0.08 & 0.32 \\
\hline
\end{tabular}


The magnitude of the capital spending multiplier increases to a peak of 60 SAR and then 50 SAR in the long run (seven years after a shock occurs). Capital spending, which contains investment in areas such as human capital, technology, and research, has been widely observed to raise longterm economic growth but exhibit little or no impact in the short run. The opposite holds for current expenditure, such as government wages, salaries, allowances, and transfers to households, which have larger growth effects in the short run compared to capital expenditure.

Comparing our findings in Table 3 with those of the earlier studies listed in Table 1, our short-run total government spending multiplier for non-oil private sector GDP of 0.1 equals that found by Espinoza et al. (2013) and is close to the 0.2 estimated by Espinoza and Senhadji (2011). It is far below the 0.9 calculated by Al-Abri et al. (2018). We note some potential shortcomings in that study. First, it estimates the short-run total government spending multiplier excluding and including outflow remittances in the VAR model, respectively. The study concludes that consideration of the remittances plays a weak, if any, role in the impact of government expenditure on non-oil GDP. These conclusions seem to be counterintuitive since macroeconomic theory articulates that outflow remittance, as a source of leakage, should reduce the magnitude of a spending multiplier, and Saudi Arabia has been ranged second or third globally in terms of amount of outflow remittances for the last five decades according to the World Bank statistics. Second, Al-Abri et al. (2018) estimate 0.9 as the short-run multiplier of total government spending for non-oil GDP but find its long-run multiplier statistically insignificant. These results do not align with the findings of the studies in Table 1 and are difficult to justify. Third, the research does not sufficiently consider econometric issues (e.g., it does not report which unit root test is used and with or without structural break; which combination of the deterministic regressors is specified in unit root test and VAR estimations; whether or not VAR models' residuals are free of serial correlation and heteroscedasticity, among other issues).

Turning to the government capital spending multiplier, our short-run multiplier is close to the 0.2 estimated by IMF (2016) for the period 1980-2015 but smaller than the 0.5 found by Espinoza and Senhadji (2011) for 1975-2009. For the long run, these two studies report capital expenditure multipliers of 0.8 and 1.0 , respectively, while a subsequent IMF (2017) study measured 0.6 for 1990-2016. Our multiplier of around 0.5 is smaller than the first two but closest to the third one found in the IMF (2017) study, which has a period of analysis also closest to ours.

Finally, our short-run current spending multiplier is very close to that found by Espinoza and Senhadji (2011) but is lower than the 0.3 observed by IMF (2016). Both IMF studies $(2016,2017)$ found long-run multipliers of 0.5, while Espinoza and Senhadji (2011) estimated 0.1 ; our 0.3 estimate falls in between.

Overall, the multipliers estimated in this research are close to, but slightly below, those reported in earlier studies. We attribute this to differences across studies in sample periods, use of non-oil total GDP versus non-oil private sector GDP, and chosen empirical procedures. ${ }^{9}$ Fouejieu et al. (2018) showed that fiscal multipliers in the Gulf Cooperation Council (GCC) countries have declined during the recent period of lower oil prices. This partially explains why our estimates, which extend through 2018 , resulted in slightly smaller multipliers than those found by previous studies that did not cover the recent period of lower oil prices. 


\section{The multipliers in bad and good times}

The literature generally observes that spending multipliers are small or insignificant during times of expansion and are large and significant during recessions (Auerbach and Gorodnichenko 2012, 2013; Ramey and Zubairy 2018; Arin et al. 2015; Mencinger et al. 2017; Biolsi 2017). This is especially true for current spending as governments usually reduce capital expenditure during recessions.

To test whether the general observation above applies to the Saudi economy, we examined the recession period of 1983-1987 and the expansion period of 2004-2010. Figure 1 illustrates that non-oil private sector GDP growth declined at an average rate of $3 \%$ annually, and $16 \%$ in total during the recession period. Conversely, during the economic boom from 2004 to 2010, non-oil private sector GDP saw an average of $10 \%$ annual growth, with a high of $13 \%$ in 2004 and a low of $6 \%$ in 2009 .

We re-specified the VAR model, which formulates the impact of government current spending on nonoil private sector GDP, to estimate the multiplier effect in the recession and expansion times. We used the partition approach of dummy variable interaction (detailed in Appendix B). The estimated VAR models for the recession and expansion states are well specified and can be used for the impulse-response analysis as they successfully pass instability, serial correlation, non-normality, or heteroscedasticity tests. The estimation and test results are documented in Table B1 of Appendix B.

Graphs A and B in Figure 4 illustrate the accumulated responses of non-oil private sector GDP growth to the shocks (Cholesky one standard deviation degree of freedom adjusted innovations) in government current spending growth in recession and expansion phases, respectively.

Graph A shows that during the recession period, the impact of current spending on non-oil private sector GDP is statistically significant and lasts less than two years, very similar to the duration of the impact of the former on the latter for the entire period shown in Panel $\mathrm{C}$ of Figure 3. This indicates that the pattern/trajectory of the effect of current spending on non-oil private sector GDP is similar regardless of whether the whole period or

Figure 4. The accumulated responses of non-oil private sector GDP to current spending.

\section{Graph A. Recession state}

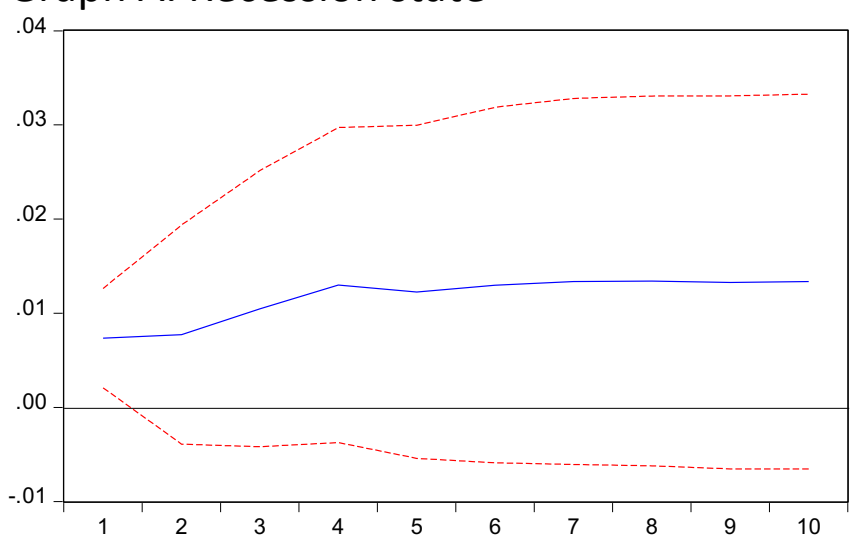

Graph B. Expansion state

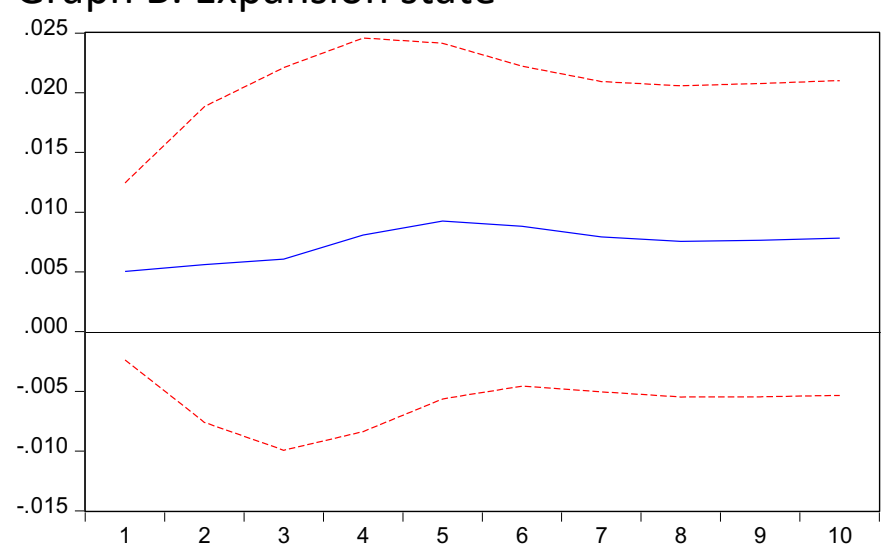


only the recession state is considered. This finding is supported by the accepted understanding in the literature of how current spending impacts the economy, as discussed above. For the recession state, we calculate a short-run multiplier for current spending of 0.22 , substantially larger than the 0.13 for the entire sample period. This aligns with theoretical expectations and the findings of previous studies. The Keynesian view states that by boosting aggregate demand, fiscal spending will have a larger positive impact on economic growth during recession than in normal times. Numerous more recent studies, including those mentioned earlier in this section, support this view. Moreover, Riera-Crichton et al. (2015) show that the magnitude of the spending multiplier in a recession depends on whether the underlying fiscal policy is countercyclical or procyclical. They estimate that the magnitude of the spending multiplier is smaller if a procyclical fiscal policy prevails compared to the higher magnitude of the multiplier with countercyclical fiscal policy.

Turning to Saudi Arabia, Panel B of Figure 2 illustrates that the growth pattern of real government current spending during 1983-1987 does not support the existence of countercyclical policy as its positive and negative growth rates followed each other (even the nominal values of current spending continuously declined from 1984 to 1986). The cumulative growth rate of real current spending was 48\% from 1983 to 1987 , and this created about $7 \%$ of growth in non-oil private sector GDP as the elasticity of the former with respect to the latter was calculated to be 0.14 from the impulse-response analysis in this section. However, if the government had followed a countercyclical policy by increasing its spending in each year during the recession period and thus had more than $48 \%$ growth, it would have brought more growth to the non-oil private sector and could have reduced the duration of the recession, as is supported by the literature (see Vegh and Vuletin 2014, among others).

Regarding the impact of current spending on non-oil private sector GDP during the expansion period, it is apparent from Graph B of Figure 4 that the impact of the former on the latter is statistically insignificant. We tested different VAR model specifications of current spending for the expansion period, but none produced a statistically significant response in non-oil private sector GDP growth to the shocks in current spending growth. Hence, we concluded that the multiplier impact of current spending is statistically insignificant during this expansion period. This is consistent with the Keynesian framework, which postulates that during economic expansion, fiscal spending increases inflation but does not create economic growth because labor and capital are already fully deployed. Indeed, we note that the 2004-2010 boom brought the highest inflation rates during the entire period of 1983-2018, supporting Keynes' view. Our findings corroborate those of Riera-Crichton et al. (2015), who observed that fiscal spending multipliers do not have a statistically significant impact on economic growth in OECD countries during economic expansion. Biolsi (2017) also found the same pattern-government spending is insignificant when the world economy is expanding, i.e., unemployment is lower than its natural level. Therefore, we conclude that Saudi Arabia's government may wish to also follow a countercyclical fiscal policy in periods of expansion. From 2004 to 2010, although government current spending growth in real terms was positive each year, its multiplier effect on the economic growth was statistically insignificant. In other words, rather than increase its current spending, the government could have directed more resources to other channels that improve economic growth such as human capital, research and development, technological improvement, or reducing public debt. 


\section{Conclusion and Policy Insights}

$\mathrm{n}$ this study, we analyzed the fiscal multipliers for Saudi Arabia's economy for a sample span that includes the recent low oil price environment. Unlike most previous research, we addressed stochastic (integration and cointegration) properties of the examined data. Additionally, we performed weak exogeneity tests to ensure that the fiscal indicators are exogenous to the non-oil sector. Moreover, we estimated fiscal multipliers for recessionary and expansionary periods to examine whether they differ substantially.

Overall, we conclude that fiscal policy plays an important role in the economic growth of the Kingdom. The findings also suggest that countercyclical fiscal policy would better support economic growth and greater spending efficiency. At the same time, the authorities may wish to keep in mind that maximizing the long-run multiplier effect of capital expenditure requires careful allocation of funds to sectors and projects with high potential impact on the economy and employment.

The Saudi government reduced its current and capital expenditure in 2015 and 2016 for fiscal consolidation purposes, but it subsequently increased spending as budget revenue streams expanded under the Fiscal Balance Program (FBP). We estimated slightly smaller multipliers than those estimated by the previous studies for Saudi Arabia. This implies that the magnitude of the possible negative effects of reduced government spending on economic growth would be smaller than previously thought. In this regard, the government may wish to consider cutting less productive current spending components, as the long-run growth effects of capital spending are estimated to be higher than those of current spending. This is also in line with the FBP initiatives to make government spending and the public sector more efficient. Studies by the IMF (e.g., Fouejieu et al. 2018) found similar results and produced the same recommendations for the GCC countries, including Saudi Arabia.

The fiscal authorities might want to pay attention to the fact that the empirical analysis showed that the magnitude of the spending multiplier is larger in a recession period than in normal times. Hence, a fiscal expansion, by increasing spending, during recessions would help the economy recover sooner than would otherwise be the case. For Saudi Arabia, this would be particularly useful now to mitigate the effects of low global oil prices and local energy price reforms. The opposite policy holds true during times of expansion. That is, the government may wish to make fiscal contractions by reducing spending during times of economic expansion, as our findings show that spending does not contribute to economic growth. Instead, the government may allocate the saved amount for projects that promote private sector economic growth in the long run or for paying external debt. 


\section{Endnotes}

${ }^{1}$ Note that values of the fiscal indicators and GDP (non-oil GDP) for recent years might be different in different SAMA Yearly Statistics releases due to revision and updating.

${ }^{2}$ We do not consider panel studies in which Saudi Arabia is included but the country-specific multiplier is not calculated or reported, such as Elkhdari et al. (2018) and Fouejieu et al. (2018).

${ }^{3}$ We analyze data starting in 1983 for two reasons. First, following the earlier multiplier studies for Saudi Arabia, we deflate fiscal indicators using the Consumer Price Index (CPI), which starts in 1980. Taking two lags of the first differenced variables in unit root and cointegration tests as well as in VAR/VECM estimations, 1983 is the earliest possible year for analysis. Second, pre-1983 data is highly volatile and distorts the analysis of the variables. Espinoza and Senhadji (2011) also state that using pre-1975 data causes coefficient instability in econometric estimations.

${ }^{4}$ Cerisola et al. (2015) estimated fiscal spending and tax multipliers employing panel structural VAR for the period 1990-2008 using panel data of 19 Middle East, North Africa and Pakistan (MENAP) countries, and stated that country-specific multipliers can be calculated for each of 31 MENAP countries. We exclude this study from Table 1 for the following reasons: (a) it does not report the country-specific multipliers; (b) although one can technically calculate multipliers for the countries, the multipliers will be calculated based on the parameters, which are estimated from pooled/panel data regression but not from the country-specific regression; (c) arguably the estimated parameters of the panel structural VAR have serious issues as our understanding is that integration, cointegration, and crosssectional dependency properties of the data have been ignored.

${ }^{5}$ The nominal values of current, capital and total expenditure for 1990 and 1991 were not reported for each year but reported as sum of these years in SAMA (2018); we took them from OE (2017).

${ }^{6}$ CPI (2013=100) values for 2001-2018 are taken from SAMA (2018) and CPI (2007=100) values for 1980-2000 are taken from OE (2017) and both re-based into $2010=100$ to be consistent with the value added of the non-oil private sector.

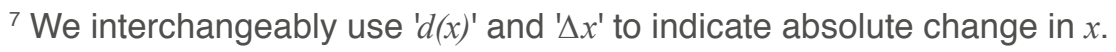

${ }^{8}$ Note that we also used VEC models to assess multipliers and the obtained results were quite close to those from the VAR models reported here.

${ }^{9}$ For example, Espinoza and Senhadji (2011) calculated the long-run multiplier using the ratio of cumulative change in non-oil GDP to the initial change in the fiscal indicators, whereas we calculate it using cumulative changes in both variables as Ramey and Zubairy (2018) discuss the pitfalls of the first approach.

${ }^{10}$ The gist of the dummy variable interaction method is that the dummy variable, which is created to capture a specific effect (for instance, recession or expansion) is multiplied by the regressor (say, government spending) whose effect is of interest.

${ }^{11}$ For example, Fouejieu et al. (2018) uses the base approach to estimate whether the impact of government spending on non-oil growth in panel data for GCC countries differs in 2008-2016 and 2011-2016 compared to the overall sample. We think they misinterpreted the impact of the interaction between the 2008-2016 dummy and government capital and current spending variables as the impact of these variables on non-oil GDP for that period. However, these interaction terms should be interpreted as whether the differences between the impacts of the current and capital spending on non-oil growth in 2008-2016 and those in 1960-2007 are statistically significant (see Gujarati and Porter 2009; Gujarati 1970). 


\section{References}

Abdih, Yasser, Pablo Lopez-Murphy, Agustin Roitman, and Ratna Sahay. 2010. "The Cyclicality of Fiscal Policy in the Middle East and Central Asia: Is the Current Crisis Different?" March 1. International Monetary Fund Working Paper no. 10/68. https://doi. org/10.5089/9781451982121.001

Al-Abri, Almukhtar, Ismail H. Genc, and George Naufal. 2018. "The Impact of Government Spending on GDP in a Remitting Country." IZA Institute of Labor Economics, IZA DP No. 11676.

Al-Hamidy, Abdulrahman. 2012. "Aspects of Fiscal/ Debt Management and Monetary Policy Interaction: the Recent Experience of Saudi Arabia." Bank of International Settlements Paper no. 67. https://doi. org/10.2139/ssrn.2205729

Almarzoqi, Raja, and Assil El Mahmah. 2019. "The Non-Oil Revenue and Economic Growth of major net oil exporters: Evidence from Saudi Arabia."

Alshahrani, S. A., and A. J. Alsadiq. 2014. "Economic Growth and Government Spending in Saudi Arabia: An Empirical Investigation." International Monetary Fund. IMF Working Paper no. 14/3. https://doi.org/10.5089/9781484348796.001

Al-Yousif, Yousif Khalifa. 2000. "Do Government Expenditures Inhibit or Promote Economic Growth: Some Empirical Evidence from Saudi Arabia." The Indian Economic Journal 48, no. 2, 92.

Arin, K. P., Faik Koray, and Nicola Spagnolo. 2015. "Fiscal Multipliers in Good Times and Bad Times." Journal of Macroeconomics 44:303-311. https://doi. org/10.1016/j.jmacro.2015.01.002

Auerbach, A. J., and Y. Gorodnichenko. 2012.

"Measuring the Output Responses to Fiscal Policy." American Economic Journal: Economic Policy 4, no. 2: 1-27. https://doi.org/10.1257/pol.4.2.1
- - . 2013. "Fiscal Multipliers in Recession and Expansion." Working Paper 17447, National Bureau of Economic Research. https://doi.org/10.3386/ w17447

Batini, Nicoletta, Luc Eyraud, Lorenzo Forni, and Anke Weber. 2014. "Fiscal Multipliers: Size, Determinants, and Use in Macroeconomic Projections." International Monetary Fund, Fiscal Affairs Department.

Biolsi, Christopher. 2017. "Nonlinear Effects Of Fiscal Policy Over The Business Cycle." Journal of Economic Dynamics and Control 78:54-87. https:// doi.org/10.1016/j.jedc.2017.03.003

Caldara, Dario, and Christophe Kamps. 2008. "What are the effects of fiscal policy shocks? A VAR-based comparative analysis." European Central Bank, Working paper series, NO 877.

Cerisola, Martin D., Chadi Abdallah, Victor Davies, and Mark Fischer. 2015. "Assessing the Impact of Fiscal Shocks on Output in MENAP Countries." International Monetary Fund.

Dickey, David A., and Wayne A. Fuller. 1981.

"Likelihood Ratio Statistics for Autoregressive Time Series with a Unit Root." Econometrica: Journal of the Econometric Society 49, no. 4 (July): 1057-1072. https://doi.org/10.2307/1912517

Enders, Walter. 2015. Applied Econometric Time Series. New Jersey: John Wiley \& Sons.

Enders, Walter, and Junsoo Lee. 2012a. "A Unit Root Test Using a Fourier Series to Approximate Smooth Breaks." Oxford Bulletin of Economics and Statistics 74, no. 4: 574-599. https://doi. org/10.1111/j.1468-0084.2011.00662.x 
- - . 2012b. "The flexible Fourier form and Dickey-Fuller type unit root tests." Economics Letters 117, no. 1: 196-199. https://doi.org/10.1016/j. econlet.2012.04.081

Engle, Robert F., and Clive W.J. Granger. 1987. "Co-integration and Error Correction: Representation, Estimation, and Testing." Econometrica: Journal of the Econometric Society 55, no. 2 (March): 251-276. https://doi. org/10.2307/1913236

Elkhdari, Maria, Moez Souissi, and Andrew Jewell. 2018. "Empirical Estimation of Fiscal Multipliers in MENA Oil-Exporting Countries with an Application to Algeria." International Monetary Fund, Working Paper, WP/18/124. https://doi. org/10.5089/9781484357972.001

Espinoza, Raphael A., and Abdelhak Senhadji. 2011. "How Strong are Fiscal Multipliers in the GCC? An Empirical Investigation." IMF Working Papers 11/61: 1-20. https://doi.org/10.5089/9781455221059.001

Espinoza, Raphael A., Ghada Fayad, and Ananthakrishnan Prasad. 2013. "The Macroeconomics of the Arab States of the Gulf." International Monetary Fund. https://doi.org/10.1093/ acprof:oso/9780199683796.001.0001

Fasano-Filho, Ugo, and Qing Wang. 2001. "Fiscal Expenditure Policy and Non-oil Economic Growth: Evidence from GCC Countries." no. 01-195. International Monetary Fund. https://doi. org/10.5089/9781451859911.001

Fatás, Antonio, and Ilian Mihov. 2001. "Government size and automatic stabilizers: international and intranational evidence." Journal of International Economics 55, no. 1: 3-28. https://doi.org/10.1016/ s0022-1996(01)00093-9
Fiscal Balance Program (FBP), Saudi Vision 2030 (SV2030). 2018. http://vision2030.gov.sa/en/bb2020

Fisher, Jonas D.M., and Ryan Peters. 2010. "Using Stock Returns to Identify Government Spending Shocks." The Economic Journal 120, no. 120:414436. https://doi.org/10.1111/j.1468-0297.2010.02355.x

Fouejieu, Armand, Sergio Rodriguez, and Sohaib Shahid. 2018. "Fiscal Adjustment in the Gulf Countries: Less Costly than Previously Thought." International Monetary Fund Working Paper, WP/18/133. https://doi. org/10.5089/9781484361573.001

Ghali, Khalifa H. 1997. "Government Spending and Economic Growth in Saudi Arabia." Journal of Economic Development 22, no. 2 (December): 165-172.

Hasanov, Fakhri J., Nader AlKathiri, Saad Alshahrani, and Ryan Alyamani. 2020a. "The Impact of Fiscal Policy on Non-Oil GDP in Saudi Arabia", KAPSARC Discussion Paper, Doi: 10.30573/ KS--2020-DP014.

Hasanov, Fakhri, Frederick L. Joutz, Jeyhun I. Mikayilov, and Muhammad Javid. 2020b. "KGEMM: A Macroeconometric Model for Saudi Arabia", KAPSARC Discussion Paper, https://doi. org/10.30573/ks--2020-dp04

Hemrit, Wael, and Noureddine Benlagha. 2018. "The impact of government spending on nonoil-GDP in Saudi Arabia (multiplier analysis)." International Journal of Economics and Business Research 15(no. 3): 350-372. https://doi.org/10.1504/ ijebr.2018.10011597 
Husain, Aasim M., Kamilya Tazhibayeva, and Anna Ter-Martirosyan. 2008. "Fiscal Policy and Economic Cycles in Oil-Exporting Countries." International Monetary Fund. Working Paper, WP/08/253. https:// doi.org/10.5089/9781451871111.001

Gujarati, Damodar. 1970. "Use of Dummy Variables in Testing for Equality between Sets of Coefficients in Two Linear Regressions: A Note." The American Statistician 24, no. 1: 50-52. https://doi.org/10.1080/0 0031305.1970 .10477181

Gujarati, Damodar N., and Dawn C. Porter. 2009. Basic Econometrics. 5th ed. New York: McGraw-Hill.

Hendry, David F., and Katarina Juselius. 2001. "Explaining Cointegration Analysis: Part II." The Energy Journal 22, no. 1: 75-120. https://doi. org/10.5547/issn0195-6574-ej-vol22-no1-4

Ilzetzki, Ethan, and Carlos A. Végh. 2008. "Procyclical Fiscal Policy in Developing Countries: Truth or Fiction?" no. w14191. National Bureau of Economic Research. https://doi.org/10.3386/w14191

Ilzetzki, Ethan, Enrique G. Mendoza, and Carlos A. Végh. 2013. "How big (small?) Are fiscal multipliers?" Journal of Monetary Economics 60, no. 2: 239-254. https://doi.org/10.1016/j.jmoneco.2012.10.011

Johansen, Søren. 1995. Likelihood-based Inference in Cointegrated Vector Autoregressive Models.

Oxford: Oxford University Press. https://doi.org/10.10 93/0198774508.001.0001

Johansen, Søren, and Katarina Juselius. 1992. "Testing structural hypothesis in a multivariate cointegration analysis of the PPP and the UIP for UK" Journal of Econometrics 53, no. 1-3: 211-244. https://doi.org/10.1016/0304-4076(92)90086-7
Joharji, Ghazi A., and Martha A. Starr. 2011. "Fiscal Policy and Growth in Saudi Arabia." Review of Middle East Economics and Finance 6, no. 3: 24-45. https://doi.org/10.2202/1475-3693.1305

Juselius, Katarina. 2006. The Cointegrated VAR Model: Methodology and Applications. Oxford: Oxford University Press.

Keynes, John Maynard. 1936. The General Theory of Employment, Interest and Money.

Kwiatkowski, Denis, Peter C.B. Phillips, Peter Schmidt, and Yongcheol Shin. 1992. "Testing the null hypothesis of stationarity against the alternative of a unit root: how sure are we that economic time series have a unit root?" Journal of Econometrics 54, no. 1-3: 159-178. https://doi. org/10.1016/0304-4076(92)90104-y

Looney, Robert E. 1986. "Socio-economic tradeoffs in Saudi Arabia's third five year plan (1980-1985)." Socio-Economic Planning Sciences 20, no. 4: 181192. https://doi.org/10.1016/0038-0121(86)90009-1

- - . 1988. "Saudi Arabia's fiscal options: 1986-1992." Socio-Economic Planning Sciences 22, no. 3: 109-123. https://doi. org/10.1016/0038-0121(88)90012-2

- - . 1989. "The Relative Efficacy of Monetary and Fiscal Policy in Saudi Arabia." Journal of International Development 1, no. 3: 356-372. https:// doi.org/10.1002/jid.3380010303

MacKinnon, James G., Alfred A. Haug, and Leo Michelis. 1999. "Numerical distribution functions of likelihood ratio tests for cointegration." Journal of Applied Econometrics 14, no. 5: 563-577. https://doi.org/10.1002/(sici)10991255(199909/10)14:5<563::aid-jae530>3.0.co;2-r 
Mencinger, Jernej, Aleksander Aristovnik, and Miroslav Verbič. 2017. "Asymmetric effects of fiscal Policy in EU and OECD countries." Economic Modelling 61:448-461. https://doi.org/10.1016/j. econmod.2016.12.023

Mountford, Andrew, and Harald Uhlig. 2009. "What are the effects of fiscal policy shocks?" Journal of Applied Econometrics 24, no. 6:960-992. https://doi. org/10.1002/jae.1079

Mustea, Lavinia. 2015. "How Large are Fiscal Multipliers in the US?" Procedia Economics and Finance 20: 423-427. https://doi.org/10.1016/ s2212-5671(15)00092-1

National Accounting (NA). 2017. The Kingdom of Saudi Arabia.

Oxford Economics (OE). 2016. Oxford Economics Global Economic Model Database, May, 2016 release.

Perron, Pierre. 2006. "Dealing with Structural Breaks." In Palgrave Handbook of Econometrics Vol. 1, no. 2, 278-352. London: Palgrave Macmillan.

Pesaran, M. Hashem, Yongcheol Shin, and Richard J. Smith. 2001. "Bounds testing approaches to the analysis of level relationships." Journal of Applied Econometrics 16, no. 3: 289-326. https://doi. org/10.1002/jae.616

Puonti, Päivi. 2016. "Fiscal multipliers in a structural VEC model with mixed normal errors." Journal of Macroeconomics 48:144-154. https://doi. org/10.1016/j.jmacro.2016.03.003

Ram, Rati. 1986. "Government Size and Economic Growth: A New Framework and Some Evidence from Cross-section and Time-series Data." The American Economic Review 76, no. 1, 191-203.
Ramey, Valerie A. 2016. "Macroeconomic Shocks and Their Propagation." In Handbook of Macroeconomics Vol. 2, 71-162.

Amsterdam: Elsevier. https://doi.org/10.1016/ bs.hesmac.2016.03.003

Ramey, Valerie A., and Sarah Zubairy. 2018. "Government Spending Multipliers in Good Times and in Bad: Evidence from US Historical Data." Journal of Political Economy 126, no. 2: 850-901. https://doi.org/10.1086/696277

Riera-Crichton, Daniel, Carlos A. Vegh, and Guillermo Vuletin. 2015. "Procyclical and countercyclical fiscal multipliers: Evidence from OECD countries." Journal of International Money and Finance 52:15-31. https://doi.org/10.1016/j. jimonfin.2014.11.011

Rubinson, Richard. 1977. "Dependence, government revenue, and economic growth, 1955-1970." Studies in Comparative International Development 12, no. 2: 3-28. https://doi.org/10.1007/bf02686481

Saudi Arabian Monetary Authority (SAMA). 2017. Yearly Statistics, June 2017 release.

- - . 2018. Yearly Statistics, May 2018 release.

- - . 2020. Yearly Statistics, July, 2020 release.

Sims, Christopher A. 1980. "Macroeconomics and Reality." Econometrica: Journal of the Econometric Society: 1-48. https://doi.org/10.2307/1912017

Sorsa, Piritta. 1999. "Algeria: The Real Exchange Rate, Export Diversification, and Trade Protection." International Monetary Fund, Working Paper no. 99/49. https://doi.org/10.5089/9781451846829.001 


\section{References}

Vegh, Carlos A., and Guillermo Vuletin. 2014. "The Road to Redemption: Policy Response to Crises in Latin America." National Bureau of Economic Research, Working Paper No. 20675. https://doi. org/10.3386/w20675

Sturm, M., M. Zimmermann, K. Schütz, W. Urban, and $\mathrm{H}$. Hartung. 2009. "Rainwater harvesting as an alternative water resource in rural sites in central northern namibia." Physics and Chemistry of the Earth, Parts A/B/C 34, no. 13-16: 776-785. https:// doi.org/10.1016/j.pce.2009.07.004

Suits, Daniel B. 1957. "Use of Dummy Variables in Regression Equations." Journal of the American Statistical Association 52, no. 280: 548-551. https:// doi.org/10.1080/01621459.1957.10501412

Uhlig, Harald. 2010. "Some Fiscal Calculus." American Economic Review 100, no. 2: 30-34. https://doi.org/10.1257/aer.100.2.30

Vermeulen, Freek, and Harry Barkema. 2001. "Learning Through Acquisitions." Academy of Management Journal 44 (3): 457-476. https://doi. org/10.2307/3069364

Vogelsang, Timothy J., and Pierre Perron. 1998. "Additional Tests for a Unit Root Allowing for a Break in the Trend Function at an Unknown Time." International Economic Review 39, no. 4 (November): 1073-1100. https://doi. org/10.2307/2527353
Wakeman-Linn, John, Paul Mathieu, and Bert van Selm. 2003. "Oil Funds and Revenue Management in Transition Economies: the Cases of Azerbaijan and Kazakhstan." In Fiscal Policy Formulation and Implementation in Oil-Producing Countries, edited by Jeffrey M. Davis, Annalisa Fedelino, and Rolando Ossows. International Monetary Fund. https://doi. org/10.5089/9781589061750.071

World Bank Open Data. 2019. Accessed October 24, 2019. https://data.worldbank.org.

World Bank (WB). 1988. World Tables. Various Issues. Baltimore: John Hopkins University Press.

Yip, Paul S. L., and Eric W. K. Tsang. 2007. "Interpreting dummy variables and their interaction effects in strategy research." Strategic Organization 5, no. 1: 13-30. https://doi. org/10.1177/1476127006073512

Zivot, E., and D. W. K. Andrews. 1992. "Further Evidence on the Great Crash, the Oil-price Shock, and the Unit-root Hypothesis." Journal of Business \& Economic Statistics 10, no. 3:251-270. https://doi. org/10.2307/1391541 


\section{Appendix A. \\ Details of the VAR/VEC estimations}

W e estimate VAR1 of yw, gt and y, VAR2 of yw, gca and y and VAR3 of yw, gcu and y. The maximum lag order is set to three. An optimal lag order of two, three and three are selected for VAR1, VAR2 and VAR3, respectively, based on the main criterion of having serial correlation free residuals. All VARs include intercept and trend. They also include a shift dummy taking unity for 20042018 and zero otherwise to capture a structural break in y, our main variable of interest, as we discussed in the main body of the paper. VAR1 additionally includes a shift dummy taking unity for 1988-2018 and zero otherwise to capture a structural break in yw (see Panel A of Figure 1) to achieve Gaussian residuals. All VARs successfully pass post-estimation tests, including stability, serial correlation, normality and heteroskedasticity. The test results are not reported here to save space but can be obtained from the authors on request.

Then we transform VAR1, VAR2 and VAR3 to VEC1, VEC2 and VEC3 models, respectively, following the methodology (Enders 2015; Juselius 2006; Hendry and Juselius 2001) to test cointegration and weak exogeneity. The results of both the cointegration and weak exogeneity tests are documented in Table A1.

Table A1. Results of the Johansen cointegration and weak exogeneity tests.

Panel A: VEC1 model

Cointegration test results

\begin{tabular}{|c|c|c|}
\hline Test statistic / test type: & Only $C$ in CE and VEC & $C$ and $t$ in CE but not $t$ in VEC \\
\hline Trace: & $40.31^{\star * *}[1]$ & $52.95^{\star \star *}[1]$ \\
\hline Max-Eigenvalue: & $26.96^{\star \star \star}[1]$ & $29.55^{\star *}[1]$ \\
\hline \multicolumn{3}{|c|}{ Weak exogeneity test results } \\
\hline & $y w$ & Jointly of $y w$ and $g t$ \\
\hline$X^{2}(1)$ & 0.52 & $4.45^{\star \star}$ \\
\hline
\end{tabular}

Panel B: VEC2 model

Cointegration test results

\begin{tabular}{lll}
\hline Test statistic / test type: & Only $C$ in CE and VEC & $38.59^{\star \star *}[1]$ \\
\hline Trace: & $28.94^{\star \star *}[1]$ & $30.53^{\star \star *}[1]$ \\
\hline Max-Eigenvalue: & $34.39^{\star \star *}[1]$ \\
\hline
\end{tabular}

Weak exogeneity test results

\begin{tabular}{llll}
$y w$ & $g c a$ & $y$ & Jointly of $y w$ and $g t$ \\
\hline 1.47 & 0.17 & $14.48^{\star * *}$ & 1.69 \\
\hline
\end{tabular}


Panel C: VEC3 model

\section{Cointegration test results}

\begin{tabular}{|c|c|c|}
\hline Test statistic / test type: & Only $C$ in CE and VEC & $C$ and $t$ in CE but not $t$ in VEC \\
\hline Trace: & $42.74^{\star \star \star}[1]$ & $60.17^{\star \star \star}[1]$ \\
\hline Max-Eigenvalue: & $31.74^{\star * *}[1]$ & $41.05^{\star \star \star}[1]$ \\
\hline \multicolumn{3}{|c|}{ Weak exogeneity test results } \\
\hline & $y w$ & Jointly of $y w$ and $g t$ \\
\hline$X^{2}(1)$ & 0.80 & $12.23^{\star \star \star}$ \\
\hline
\end{tabular}

Notes. The null hypothesis in the cointegration test is that there is no cointegration among the variables. The critical values are from Mackinnon et al. (1999). The null hypothesis in the weak exogeneity test is that a given variable is weakly exogenous; $\mathrm{C}$, $\mathrm{t}$ and CE mean Intercept, linear trend and Cointegration Equation, respectively; Values in brackets indicate number of cointegrated equations found by Trace and Max-Eigenvalues tests; ***, ** and * denote rejection of the null hypotheses at the $1 \%, 5 \%$, and $10 \%$ significance levels, respectively; Estimation period: 1983-2018.

In the cointegration test, we focus on two options: the intercept and trend and intercept only. These are more widely adopted in empirical analyses of socioeconomic relationships than other test options, and thus more relevant to this study. The trend option also provides a proxy for the other determinants of output, such as capital and labor, that are not included in the analysis because of the small size of the sample and they are not interests of the present research here. 
Table A2. VAR post-estimation test results.

Panel A: VAR1

\begin{tabular}{lll}
\multicolumn{2}{l}{ A1: Serial Correlation LM Test } & \\
\hline Lags & LM-Statistic & $\boldsymbol{p}$-Value \\
\hline 1 & 7.81 & 0.55 \\
\hline 2 & 10.24 & 0.33 \\
\hline 3 & 6.92 & 0.65 \\
\hline
\end{tabular}

A2: Normality Test ${ }^{\mathrm{b}}$

\begin{tabular}{llll}
\hline Statistic & Value & d.f. & $p$-Value \\
\hline Skewness & -0.47 & 1 & 0.25 \\
\hline Kurtosis & 3.46 & 1 & 0.57 \\
\hline Jarque-Bera & 1.65 & 2 & 0.44
\end{tabular}

A3: Heteroscedasticity Test ${ }^{c}$

\begin{tabular}{llll}
\hline Statistic & $\chi^{2}$ & d.f. & $p$-Value \\
\hline White & 197.17 & 174 & 0.11 \\
\hline
\end{tabular}

\section{A4: Stability Test $^{d}$}

\begin{tabular}{ll}
\hline Modulus & Root \\
\hline 0.73 & 0.73 \\
\hline 0.57 & $0.03-0.564954 \mathrm{i}$ \\
\hline 0.57 & $0.03+0.564954 \mathrm{i}$
\end{tabular}

\section{Panel B: VAR2}

B1: Serial Correlation LM Test ${ }^{\text {a }}$

\begin{tabular}{lll}
\hline Lags & LM-Statistic & $p$-Value \\
\hline 1 & 12.70 & 0.18 \\
\hline 2 & 14.07 & 0.12 \\
\hline 3 & 4.44 & 0.88 \\
\hline
\end{tabular}

B2: Normality Test ${ }^{\mathrm{b}}$

\begin{tabular}{llll}
\hline Statistic & Value & d.f. & $p$-Value \\
\hline Skewness & -0.56 & 1 & 0.17 \\
\hline Kurtosis & 4.17 & 1 & 0.15 \\
\hline Jarque-Bera & 3.96 & 2 & 0.14 \\
\hline
\end{tabular}

B3: Heteroscedasticity Test ${ }^{\mathrm{c}}$

\begin{tabular}{llll}
\hline Statistic & $\chi^{2}$ & d.f. & $p$-Value \\
\hline White & 196.74 & 174 & 0.11 \\
\hline
\end{tabular}

B4: Stability Test ${ }^{d}$

\begin{tabular}{ll}
\hline Modulus & Root \\
\hline 0.71 & $-0.17-0.684964 i$ \\
\hline 0.51 & $-0.17+0.684964 i$ \\
\hline 0.61 & $0.58-0.174228 \mathrm{i}$ \\
\hline
\end{tabular}

\section{Panel C: VAR3}

C1: Serial Correlation LM Test ${ }^{\text {a }}$

\begin{tabular}{lll}
\hline Lags & LM-Statistic & $p$-Value \\
\hline 1 & 6.69 & 0.67 \\
\hline 2 & 9.02 & 0.44 \\
\hline 3 & 7.58 & 0.58 \\
\hline C2: Normality Test $^{\text {b }}$ &
\end{tabular}

\begin{tabular}{llll}
\hline Statistic & Value & d.f. & $p$-Value \\
\hline Skewness & -0.37 & 1 & 0.36 \\
\hline Kurtosis & 3.69 & 1 & 0.40 \\
\hline Jarque-Bera & 1.54 & 2 & 0.46 \\
\hline
\end{tabular}

\section{C3: Heteroscedasticity Test ${ }^{\mathrm{c}}$}

\begin{tabular}{llll}
\hline Statistic & $\chi^{2}$ & d.f. & $p$-Value \\
\hline White & 185.45 & 168 & 0.17 \\
\hline
\end{tabular}

C4: Stability Test ${ }^{d}$

\begin{tabular}{ll}
\hline Modulus & Root \\
\hline 0.71 & $-0.12-0.694863 \mathrm{i}$ \\
\hline 0.71 & $-0.12+0.694863 \mathrm{i}$ \\
\hline 0.64 & $0.60-0.207896 \mathrm{i}$ \\
\hline
\end{tabular}

Notes: We estimate VAR1 of $\Delta y w, \Delta g t$ and $\Delta y$, VAR2 of $\Delta y w$, $\Delta g c a$ and $\Delta y$ and VAR3 of $\Delta y w, \Delta g c u$ and $\Delta y$.

In all three VAR models, we set lag length to two (as we have a small sample size) and this was enough to remove serial correlations from the residuals as the serial correlation LM test results indicate here.

All VARs include intercept. They also include a dummy variable to capture a large jump in $\Delta y$ in 2004 (see Panel B of Figure 2). Additionally, VAR1 includes a dummy variable to capture a big jump in $\Delta y w$ in 1988 and VAR2 includes a dummy variable to capture a large drop in $\Delta g c a$ in 1993 (see Panel B of Figure 2) to achieve Gaussian residuals.

a The null hypothesis in the serial correlation LM test is that there is no serial correlation at lag order $h$ of the residuals; ${ }^{\mathrm{b}}$ System normality tests for $\Delta y$ equation with the null hypothesis of the residuals are normally distributed; ${ }^{\circ}$ The White heteroscedasticity test takes the null hypothesis of no heteroscedasticity in the residuals; ${ }^{d}$ VAR stability test results show that all VARs are stable, that is no roots of polynomial characteristic are outside the unit circle; $\chi^{2}$ is chi-squared; d.f. means degree of freedom.

Estimation period: 1983-2018. 


\section{Appendix B.}

\section{Technical aspects of estimating multipliers in recession and expansion states}

\section{B1. Dummy variable interaction method}

As mentioned above, we considered the recession period of 1983-1987 and the expansion period of 2004-2010 based on the time profile of non-oil private sector GDP. Because a VAR model cannot be run on these periods separately, we employed the dummy variable interaction method, which is the conventional approach in the literature for such analysis (see, for example, Gujarati and Porter, 2009)..$^{10}$ We prefer applying the partition approach dummy variable interaction to base approach dummy variable interaction (see Suits 1957; Gujarati 1970; Vermeulen and Barkema 2001; Yip and Tsang 2007 for theory and application of both approaches). Although they are mathematically equivalent and thus can be derived from each other, they have different interpretations and Yip and Tsang (2007) show that sometimes researchers misinterpret the role of the dummy variable in the base approach. ${ }^{11}$ Their study also discusses a number of advantages of the partition approach over the base approach.

Hence, we used the partition approach dummy variable interaction. The non-oil private sector GDP growth rate equation in VAR4 below takes the following specification to reflect the impact of the current spending in the recession state:

$$
\Delta y_{t}=\alpha_{0}+\sum_{i=1}^{p 1} \alpha_{1 i} \Delta y_{t-i}+\sum_{i=1}^{p 1} \alpha_{2 i} \Delta y w_{t-i}+\sum_{i=1}^{p 1} \alpha_{3 i} D R * \Delta g c u_{t-i}+\sum_{i=1}^{p 1} \alpha_{4 i} D R^{\prime} * \Delta g c u_{t-i}+u_{t}
$$

Here, $p 1$ is the lag order; $\alpha$ s are the coefficients to be estimated; $u$ is the error term. $D R$ takes unity in 1983-1987 and zero otherwise. $D R^{\prime}$ takes unity in 1988-2018 and zero otherwise, i.e., $D R^{\prime}=1-D R$.

Similarly, non-oil private sector GDP growth rate equation in VAR5 below takes the following form to capture the effect of the current spending in the expansion state:

$$
\Delta y_{t}=b_{0}+\sum_{i=1}^{p 2} b_{1 i} \Delta y_{t-i}+\sum_{i=1}^{p 2} b_{2 i} \Delta y w_{t-i}+\sum_{i=1}^{p 2} b_{3 i} D E * \Delta g c u_{t-i}+\sum_{i=1}^{p 2} b_{4 i} D E^{\prime} * \Delta g c u_{t-i}+v_{t}
$$

Here, $p 2$ is the lag order; $b$ s are the coefficients to be estimated; $v$ is the error term. $D E$ takes unity in 2004-2010 and zero otherwise. $D E^{\prime}$ takes unity in 1983-2003 and 2011-2018 and zero otherwise,

i.e., $D E^{\prime}=1-D E$. 
Table B1. VAR post-estimation test results.

Panel A: VAR4

\begin{tabular}{lll}
\multicolumn{2}{l}{ A1: Serial Correlation LM Test } \\
\hline Lags & LM-Statistic & $\boldsymbol{p}^{\mathrm{a}}$-Value \\
\hline 1 & 14.63 & 0.55 \\
\hline 2 & 16.75 & 0.40 \\
\hline 3 & 20.56 & 0.20 \\
\hline
\end{tabular}

A2: Normality Test ${ }^{\mathrm{b}}$

\begin{tabular}{lccl}
\hline Statistic & Value & d.f. & $p$-Value \\
\hline Skewness & -0.44 & 1 & 0.28 \\
\hline Kurtosis & 2.96 & 1 & 0.96 \\
\hline Jarque-Bera & 1.17 & 2 & 0.56 \\
\hline
\end{tabular}

A3: Heteroscedasticity Test ${ }^{c}$

\begin{tabular}{llll}
\hline Statistic & $\chi^{2}$ & d.f. & $p$-Value \\
\hline White & 187.70 & 180 & 0.33 \\
\hline
\end{tabular}

A4: Stability Test ${ }^{d}$

\begin{tabular}{ll}
\hline Modulus & Root \\
\hline 0.79 & $-0.04-0.785487 \mathrm{i}$ \\
\hline 0.79 & $-0.04+0.785487 \mathrm{i}$ \\
\hline 0.56 & $-0.16-0.536169 \mathrm{i}$ \\
\hline
\end{tabular}

Notes: VAR4 includes the endogenous variables of $\Delta y w, D R^{*} \Delta g c u, D R^{*} \Delta g c u$ and $\Delta y$. VAR5 includes the endogenous variables of $\Delta y w, D E^{*} \Delta g c u, D E^{* *} \Delta g c u$ and $\Delta y$.

The exogenous variables of Intercept and $D R$ are included in VAR4 and Intercept and $D E$ are included in VAR5 following the discussion in Gujarati and Porter (2009) and Gujarati (1970). Additionally, DP2004 and DP1986 are included in VAR4 and VAR5, respectively, to capture large outliers in the residuals, which distort the Gaussian conditions. These dummy variables take unity in 2004 and 1986, respectively, and zero otherwise.

In both the VAR models, we set lag length to two (as we have a small sample size) and this lag order was enough to remove serial correlations from the residuals as the LM test results indicate here.

a The null hypothesis in the serial correlation LM test is that there is no serial correlation at lag order $\mathrm{h}$ of the residuals; ${ }^{\mathrm{b}}$ System normality tests for $\Delta y$ equation with the null hypothesis of the residuals are normally distributed; ${ }^{c}$ The White heteroscedasticity test takes the null hypothesis of no heteroscedasticity in the residuals; ${ }^{d}$ VAR stability test results show that all VARs are stable that is no roots of polynomial characteristic are outside the unit circle; $\chi^{2}$ is chi-squared; d.f. means degree of freedom.

Estimation period: 1983-2018.

Panel B: VAR5

\begin{tabular}{|c|c|c|c|}
\hline \multicolumn{4}{|c|}{ B1: Serial Correlation LM Test ${ }^{a}$} \\
\hline Lags & \multicolumn{2}{|c|}{ LM-Statistic } & $p$-Value \\
\hline 1 & \multicolumn{2}{|l|}{13.24} & 0.66 \\
\hline 2 & \multicolumn{2}{|l|}{17.45} & 0.36 \\
\hline 3 & \multicolumn{2}{|l|}{19.66} & 0.24 \\
\hline \multicolumn{4}{|c|}{ B2: Normality Test ${ }^{\mathrm{b}}$} \\
\hline Statistic & Value & d.f. & $p$-Value \\
\hline Skewness & -0.11 & 1 & 0.78 \\
\hline Kurtosis & 2.79 & 1 & 0.79 \\
\hline Jarque-Bera & 0.15 & 2 & 0.93 \\
\hline \multicolumn{4}{|c|}{ B3: Heteroscedasticity Test ${ }^{c}$} \\
\hline Statistic & $\chi^{2}$ & d.f. & $p$-Value \\
\hline White & 206.82 & 180 & 0.08 \\
\hline \multicolumn{4}{|c|}{ B4: Stability Test ${ }^{d}$} \\
\hline Modulus & \multicolumn{3}{|l|}{ Root } \\
\hline 0.72 & \multicolumn{3}{|c|}{$-0.13-0.702945 i$} \\
\hline 0.72 & \multicolumn{3}{|c|}{$-0.13+0.702945 i$} \\
\hline 0.65 & \multicolumn{3}{|c|}{$0.14-0.637261 i$} \\
\hline
\end{tabular}

\section{B2: Normality Test ${ }^{\mathrm{b}}$}

\begin{tabular}{|c|c|c|c|}
\hline \multicolumn{4}{|c|}{ B1: Serial Correlation LM Test ${ }^{a}$} \\
\hline Lags & \multicolumn{2}{|c|}{ LM-Statistic } & $p$-Value \\
\hline 1 & \multicolumn{2}{|l|}{13.24} & 0.66 \\
\hline 2 & \multicolumn{2}{|l|}{17.45} & 0.36 \\
\hline 3 & \multicolumn{2}{|l|}{19.66} & 0.24 \\
\hline \multicolumn{4}{|c|}{ B2: Normality Test ${ }^{\mathrm{b}}$} \\
\hline Statistic & Value & d.f. & $p$-Value \\
\hline Skewness & -0.11 & 1 & 0.78 \\
\hline Kurtosis & 2.79 & 1 & 0.79 \\
\hline Jarque-Bera & 0.15 & 2 & 0.93 \\
\hline \multicolumn{4}{|c|}{ B3: Heteroscedasticity Test ${ }^{c}$} \\
\hline Statistic & $\chi^{2}$ & d.f. & $p$-Value \\
\hline White & 206.82 & 180 & 0.08 \\
\hline \multicolumn{4}{|c|}{ B4: Stability Test ${ }^{d}$} \\
\hline Modulus & \multicolumn{3}{|l|}{ Root } \\
\hline 0.72 & \multicolumn{3}{|c|}{$-0.13-0.702945 i$} \\
\hline 0.72 & \multicolumn{3}{|c|}{$-0.13+0.702945 i$} \\
\hline 0.65 & \multicolumn{3}{|c|}{$0.14-0.637261 i$} \\
\hline
\end{tabular}

\section{B3: Heteroscedasticity Test}

\begin{tabular}{|c|c|c|c|}
\hline \multicolumn{4}{|c|}{ B1: Serial Correlation LM Test ${ }^{a}$} \\
\hline Lags & \multicolumn{2}{|c|}{ LM-Statistic } & $p$-Value \\
\hline 1 & \multicolumn{2}{|l|}{13.24} & 0.66 \\
\hline 2 & \multicolumn{2}{|l|}{17.45} & 0.36 \\
\hline 3 & \multicolumn{2}{|l|}{19.66} & 0.24 \\
\hline \multicolumn{4}{|c|}{ B2: Normality Test ${ }^{\mathrm{b}}$} \\
\hline Statistic & Value & d.f. & $p$-Value \\
\hline Skewness & -0.11 & 1 & 0.78 \\
\hline Kurtosis & 2.79 & 1 & 0.79 \\
\hline Jarque-Bera & 0.15 & 2 & 0.93 \\
\hline \multicolumn{4}{|c|}{ B3: Heteroscedasticity Test ${ }^{c}$} \\
\hline Statistic & $\chi^{2}$ & d.f. & $p$-Value \\
\hline White & 206.82 & 180 & 0.08 \\
\hline \multicolumn{4}{|c|}{ B4: Stability Test ${ }^{d}$} \\
\hline Modulus & \multicolumn{3}{|l|}{ Root } \\
\hline 0.72 & \multicolumn{3}{|c|}{$-0.13-0.702945 i$} \\
\hline 0.72 & \multicolumn{3}{|c|}{$-0.13+0.702945 i$} \\
\hline 0.65 & \multicolumn{3}{|c|}{$0.14-0.637261 i$} \\
\hline
\end{tabular}

\section{B4: Stability Test ${ }^{d}$}

\begin{tabular}{|c|c|c|c|}
\hline \multicolumn{4}{|c|}{ B1: Serial Correlation LM Test ${ }^{a}$} \\
\hline Lags & \multicolumn{2}{|c|}{ LM-Statistic } & $p$-Value \\
\hline 1 & \multicolumn{2}{|l|}{13.24} & 0.66 \\
\hline 2 & \multicolumn{2}{|l|}{17.45} & 0.36 \\
\hline 3 & \multicolumn{2}{|l|}{19.66} & 0.24 \\
\hline \multicolumn{4}{|c|}{ B2: Normality Test ${ }^{\mathrm{b}}$} \\
\hline Statistic & Value & d.f. & $p$-Value \\
\hline Skewness & -0.11 & 1 & 0.78 \\
\hline Kurtosis & 2.79 & 1 & 0.79 \\
\hline Jarque-Bera & 0.15 & 2 & 0.93 \\
\hline \multicolumn{4}{|c|}{ B3: Heteroscedasticity Test ${ }^{c}$} \\
\hline Statistic & $\chi^{2}$ & d.f. & $p$-Value \\
\hline White & 206.82 & 180 & 0.08 \\
\hline \multicolumn{4}{|c|}{ B4: Stability Test ${ }^{d}$} \\
\hline Modulus & \multicolumn{3}{|l|}{ Root } \\
\hline 0.72 & \multicolumn{3}{|c|}{$-0.13-0.702945 i$} \\
\hline 0.72 & \multicolumn{3}{|c|}{$-0.13+0.702945 i$} \\
\hline 0.65 & \multicolumn{3}{|c|}{$0.14-0.637261 i$} \\
\hline
\end{tabular}




\section{Notes}

(1) 
Notes

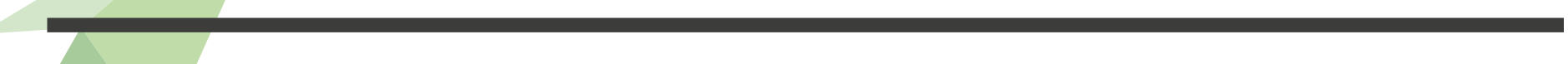




\section{Notes}




\section{About the Authors}

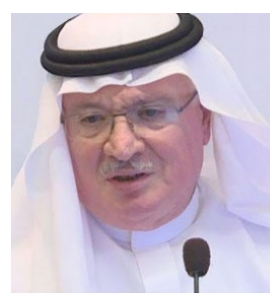

\section{H.E. Dr. Majid Al Moneef}

H.E. Dr. Majid Al Moneef is Chairman of the International Advisory Committee of KAPSARC and the former Secretary General of the Supreme Economic Council of Saudi Arabia. He was the president of the Saudi Economic Association and a professor of economics at King Saud University in Saudi Arabia.

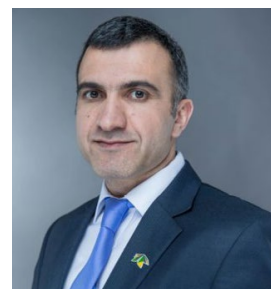

\section{Fakhri J. Hasanov}

Fakhri Hasanov is a senior research fellow and the KAPSARC Global Energy Macroeconometric Model (KGEMM) project lead. His research experience spans econometric modeling and forecasting, the application of macroeconometric models for policy analyses, and energy economics, with a particular focus on natural resource rich countries.

\section{About the Project}

This study, led by H.E. Dr. Majid AI Moneef, was part of the KGEMM Research and Policy Studies project. The project aims to conduct research and policy studies that enhance the understanding of the Kingdom of Saudi Arabia's macroeconomic-energy environment and are useful for Saudi Arabian decision-makers when considering policy measures. 
INAPSARC

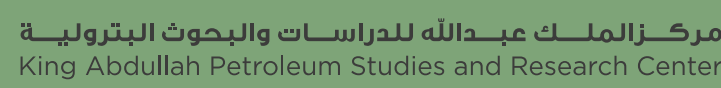

www.kapsarc.org 